\title{
Century-Old Mystery of Puccinia striiformis Life History Solved with the Identification of Berberis as an Alternate Host
}

\author{
Yue Jin, Les J. Szabo, and Martin Carson
}

U.S. Department of Agriculture-Agricultural Research Service, Cereal Disease Laboratory, University of Minnesota, St. Paul 55108. Accepted for publication 7 January 2010.

\begin{abstract}
Jin, Y., Szabo, L. J., and Carson, M. 2010. Century-old mystery of Puccinia striiformis life history solved with the identification of Berberis an an alternate host. Phytopathology 100:432-435.

The life history of Puccinia striiformis remains a mystery because the alternate host has never been identified. Inoculation of grasses using aeciospores from naturally infected Berberis chinensis and B. koreana resulted in infection on Poa pratensis, producing uredinia typical of stripe

and $B$. vulgaris after inoculation using germinating telia of $P$. striiformis f. sp. tritici. Wheat inoculated with aeciospores from $B$. chinensis resulted in uredinia, which demonstrated that Berberis spp. also serve as alternate hosts for the wheat stripe rust pathogen. The elucidation of the complete life history for P. striiformis f. sp. tritici will provide a powerful tool to rapidly advance our knowledge of the genetics of this rust fungus, and will lead to the development of improved strategies for a better control of stripe rust.
\end{abstract} rust caused by $P$. striiformis. Analyses using real-time polymerase chain reaction and DNA sequence confirmed the rust fungus as $P$. striiformis. Pycnia and aecia were produced on B. chinensis, B. holstii, B. koreana,
Additional keywords: aecial host, life cycle.
Life histories (or life cycles) of most rust fungi attacking cereal crops and grasses have been well understood for more than a century. The life history of Puccinia striiformis, the causal organism of stripe (or yellow) rust of important cereal crops and grasses, remains a mystery because the alternate (or aecial) host for $P$. striiformis has never been identified although it has been assumed that $P$. striiformis is a macrocyclic, heteroecious fungus, based on similarities with other cereal rust fungi. Attempts to identify the alternate host by infecting various suspected plant species with germinating teliospores of $P$. striiformis have failed $(4,11,15)$. Mains (10) suspected Berberis and Mahonia could be alternate hosts of $P$. striiformis because of its relatedness to $P$. koeleriae, $P$. arrhenatheri, and $P$. montanensis that are rusts of Berberis. Hart and Becker (5) followed this lead but failed to produce infection on Berberis or Mahonia with teliospores of $P$. striiformis. Due to these failures and a fact that the fungus reproduces asexually through urediniospores that can sustain itself clonally by re-infecting the telial hosts, the existence of an alternate host for $P$. striiformis in nature has been doubted (6).

In June 2009, we observed severe aecial infection on $B$. chinensis, and light infections on B. koreana and on 'Emerald Carousel', an interspecific hybrid between $B$. koreana and $B$. thunbergii. Preliminary inoculation on grasses using aeciospores resulted in infection only on Poa pratensis, producing uredinia typical of stripe rust caused by $P$. striiformis, suggesting that Berberis spp. might be an aecial host of this rust fungus. We report the identification of aecial hosts of $P$. striiformis $\mathrm{f}$. sp. poae, and the elucidation of the complete life history of $P$. striiformis f. sp. tritici.

Corresponding author: Y. Jin; E-mail address: yue.jin@ars.usda.gov

doi:10.1094/PHYTO-100-5-0432

This article is in the public domain and not copyrightable. It may be freely reprinted with customary crediting of the source. The American Phytopathological Society, 2010.

\section{MATERIALS AND METHODS}

Inoculation on grasses using aeciospores. Leaves of $B$. chinensis, B. koreana and 'Emerald Carousel', an interspecific hybrid between $B$. koreana and $B$. thunbergii, with natural aecial infections were collected from specimen plants grown in the University of Minnesota arboretum in Chaska (MN) and ornamental plantings of Emerald Carousel in St. Paul (MN) in June 2009. Aecia-bearing leaves were suspended over seedling plants of wheat (cv. Chinese Spring and Line E), barley (cv. Hiproly and Hypana), oat (cv. Marvelous), rye (cv. Prolific), and Kentucky blue grass (Poa pratensis). Plants were incubated in an inoculation chamber for $16 \mathrm{~h}$ at 18 to $20^{\circ} \mathrm{C}$ in the dark. The chamber was intermittently misted to ensure high humidity $(\approx 100 \%$ relative humidity) and maintain free moisture on leaf surfaces. After inoculation, plants were maintained in a growth chamber at 18 to $20^{\circ} \mathrm{C}$ with a photoperiod of $12 \mathrm{~h}$.

Inoculation on Berberis spp. using telia of $P$. striiformis $\mathbf{f}$. $\mathbf{s p .}$ tritici. Wheat straw bearing telia of $P$. striiformis f. sp. tritici was harvested from an experimental field at the University of California, Davis (CA). Leaf tissue was soaked in water for $24 \mathrm{~h}$, rinsed thoroughly, and maintained moist by wrapping in moistened paper towel. Teliospore germination was monitored by plating teliospores onto water-agar plates and periodically observing the plates under a microscope. When teliospore germination was detected (usually $48 \mathrm{~h}$ after plating), straw was suspended over plants of $B$. chinensis, $B$. holstii, B. koreana, and $B$. vulgaris, and plants were incubated for 4 days in a mist chamber with a diurnal temperature regime $\left(12\right.$-h night at $12^{\circ} \mathrm{C}$ and 12 -h day at $15^{\circ} \mathrm{C}$ ). After inoculation and incubation, plants were maintained in a growth cabinet at the same diurnal temperature/light regimes.

Inoculation on Line $\mathbf{E}$ wheat using resultant aeciospores produced on $\boldsymbol{B}$. chinensis. Leaves of $B$. chinensis bearing aecia from telial inoculation were placed onto a piece of filter paper saturated with water in a petri plate for $6 \mathrm{~h}$ to promote the release of aeciospores. Water drops were placed onto aeciospore masses to make an aeciospore suspension. Seedlings of Line E wheat 
were inoculated by applying spore suspension onto surfaces of primary leaves using a cotton swab. Inoculated plants were incubated for $24 \mathrm{~h}$ in a mist chamber with a diurnal temperature regime $\left(12\right.$-h night at $12^{\circ} \mathrm{C}$ and 12 -h day at $\left.15^{\circ} \mathrm{C}\right)$. After inoculation and incubation, plants were maintained in a growth cabinet at the same diurnal temperature/light regimes. Uredinia were produced 12 days after inoculation.

DNA analysis. DNA was extracted from dried host tissue (20 to $30 \mathrm{mg}$ ) containing aecial, telial, or uredinial pustules. Infected leaf tissue was pulverized as described by Anikster et al. (1). DNA was isolated from pulverized tissue using an OmniPrep DNA extraction kit (GenoTech, St. Louis). Real-time polymerase chain reaction (PCR) assays specific for identification of $P$. graminis and $P$. striiformis were performed as described by Barnes and Szabo (2) using a LightCycler 480 (Roche, Indianapolis, IN). The nuclear ribosomal internal transcribed spacer (ITS) region and the 5 '-end of the large subunit were amplified using PCR primers
ITS1F and RUST1 as described (1). Amplification products were purified, cloned, and sequenced (1). DNA sequence alignment and phylogenetic analysis using parsimony were preformed as described (14). Nucleotide sequence data have been submitted as GenBank accession numbers GQ457304 to GQ457307 and GU382671 to GU382673.

\section{RESULTS}

Inoculations of wheat, barley, rye, oat, and Poa pratensis using aeciospores from B. chinensis (Fig. 1A) resulted in infection only on Poa pratensis, producing uredinia typical of stripe rust caused by $P$. striiformis (Fig. 1B). Inoculations on Poa pratensis using aeciospores from $B$. koreana and Emerald Carousel also produced uredinia typical of stripe rust. The rust fungus causing the aecial infections on Berberis spp. and uredinial infections on Poa pratensis was identified as $P$. striiformis by real-time PCR (Table

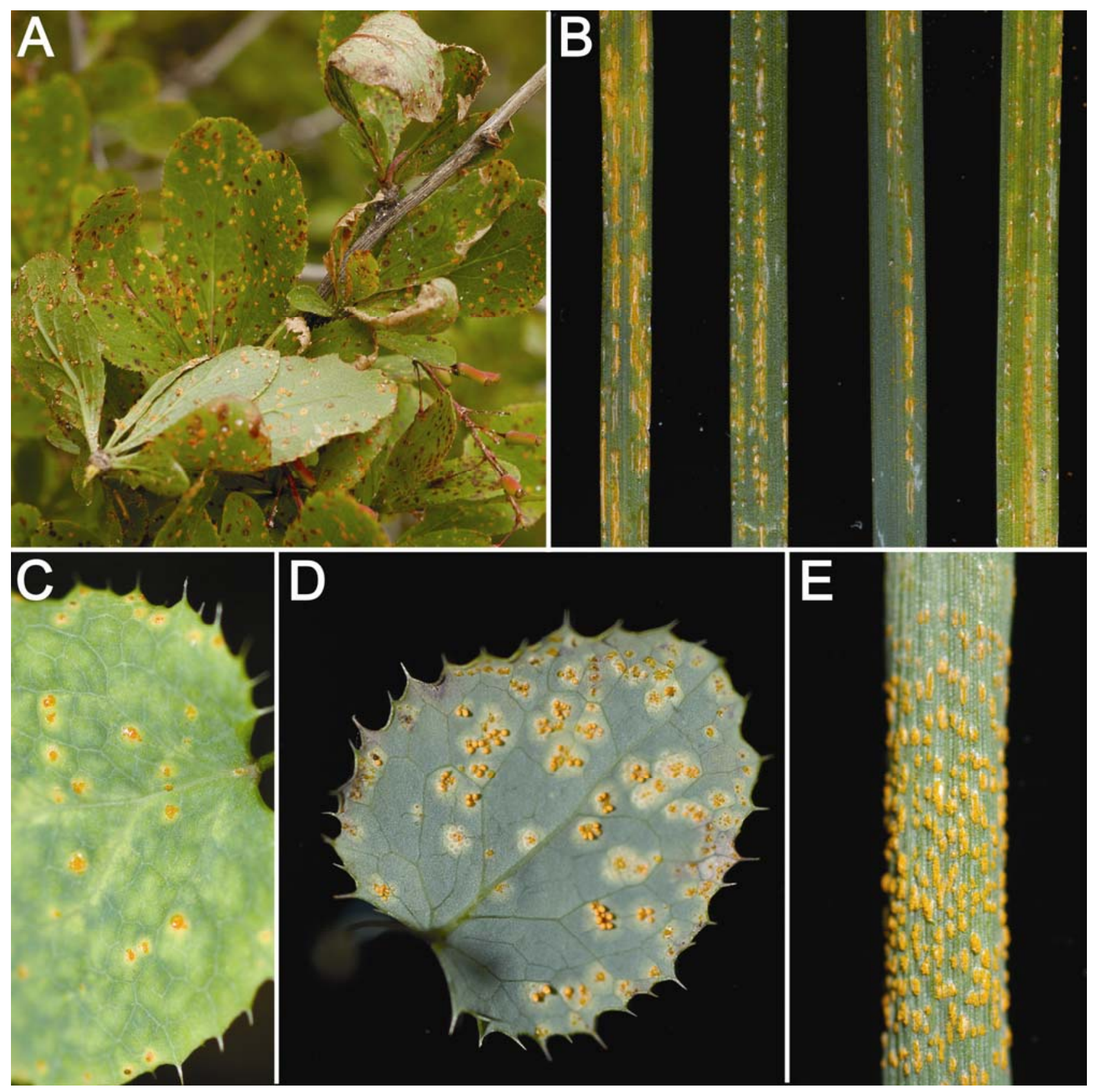

Fig. 1. A, Aecial infection on Berberis chinensis plants in the field; B, uredinia produced on Poa pratensis through inoculation with aeciospores from B. chinensis; $\mathbf{C}$, pycnia and $\mathbf{D}$, aecia produced on seedling plants of B. chinensis through inoculation with germinating teliospores of Puccinia striiformis f. sp. tritici; and $\mathbf{E}$, uredinia produced on Line $\mathrm{E}$ wheat after inoculation with aeciospores from B. chinensis shown in $\mathbf{D}$. 


\begin{tabular}{|c|c|c|c|c|c|}
\hline \multirow[b]{2}{*}{ Sample $^{\mathrm{a}}$} & \multirow[b]{2}{*}{ Host } & \multirow[b]{2}{*}{ Life-cycle stage } & \multirow[b]{2}{*}{ Location } & \multicolumn{2}{|c|}{ Real-time $\mathrm{PCR}^{\mathrm{b}}$} \\
\hline & & & & P. graminis & P. striiformis \\
\hline HSZ1828 & Berberis $\times$ Emerald Carousel & Aecia & St. Paul, MN & - & + \\
\hline HSZ1829 & Berberis $\times$ Emerald Carousel & Aecia & St. Paul, MN & - & + \\
\hline HSZ1831 & Berberis $\times$ Emerald Carousel & Aecia & Chaska, MN & - & + \\
\hline HSZ1832 & Berberis chinensis & Aecia & Chaska, MN & - & + \\
\hline HSZ1833 & B. koreana & Aecia & Chaska, MN & - & + \\
\hline HSZ1834 & B. koreana & Aecia & Chaska, MN & - & + \\
\hline HSZ1836 & Poa pratensis & Uredinia & - & - & + \\
\hline $\mathrm{HSZ} 1837^{\mathrm{c}}$ & Poa pratensis & Uredinia & - & - & + \\
\hline HSZ1838c & Poa pratensis & Uredinia & - & - & + \\
\hline HSZ1847 & Triticum aestivum & Telia & Davis, CA & - & + \\
\hline HSZ1849 & B. chinensis & Aecia & - & - & + \\
\hline $\mathrm{HSZ1872}$ & T. aestivum & Uredinia & - & - & + \\
\hline P. graminis & T. aestivum & Uredinia & - & + & - \\
\hline P. striiformis & T. aestivum & Uredinia & - & - & + \\
\hline
\end{tabular}

a Samples were stored in rust collection at the U.S. Department of Agriculture, Agricultural Research Service, Cereal Disease Laboratory, St. Paul, MN.

b Positive (+) assay with crossing point value of $<30$; negative $(-)$.

c Uredinia formed by inoculating Poa pratensis with aeciospores from B. chinensis (HSZ1832).

${ }^{\mathrm{d}}$ Aecia formed by inoculating B. chinensis with germinating teliospores of $P$. striiformis $\mathrm{f}$. sp. tritici (HSZ1847).

e Uredinia formed by inoculating T. aestivum (Line E) with aeciospores from B. chinensis (HSZ1849).

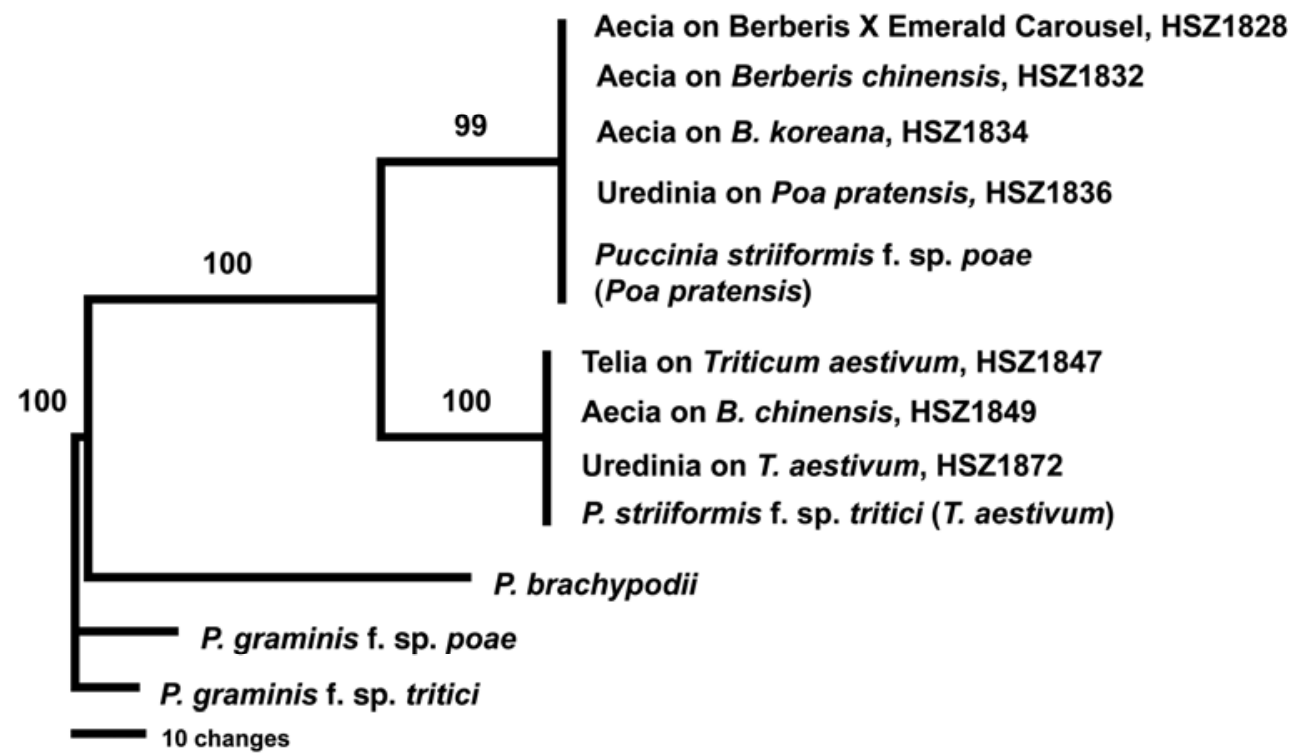

Fig. 2. Phylogenetic tree of Puccinia striiformis samples based on nuclear ribosomal internal transcribed spacer sequence data. Parsimony analysis resulted in an optimal tree with a length of 115 steps. Numbers above branches indicate percentage of congruent clusters in 5,000 bootstrap trials. Reference sequences used in the analysis included: P. brachypodii (GQ457303); P. graminis f. sp. poae (DQ417389); P. graminis f. sp. tritici (DQ417374); P. striiformis f. sp. poae (DQ417407); and P. striiformis f. sp. tritici (DQ417394).

1). DNA sequence analysis of the nuclear ribosomal internal transcribed region confirmed the identification and determined that it was $P$. striiformis f. sp. poae (Fig. 2).

Among several cereal rust fungi, including $P$. graminis and $P$. coronata, of which their host specificities and complete life cycles are well-known, different formae speciales of the same species share a common aecial host $(7,9)$. We hypothesized that $P$. striiformis $\mathrm{f}$. sp. tritici, the forma specialis specialized on wheat, also uses Berberis spp. as an alternate host. To test this hypothesis, freshly harvested wheat straw bearing telia of $P$. striiformis $\mathrm{f}$. sp. tritici was used to inoculate several members of Berberis: $B$. chinensis, B. holstii, B. koreana, and B. vulgaris. Pycnia were produced at 8 days (Fig. 1C) and aecia were produced 14 days postinoculation on B. chinensis (Fig. 1D), B. holstii, and $B$. vulgaris. Aecia production on $B$. koreana appeared to be limited. Aeciospores from $B$. chinensis were used to inoculate wheat Line $\mathrm{E}$, producing uredinia typical of stripe rust (Fig. 1E) 12 days after inoculation. Real-time PCR and DNA sequence analyses of the ITS region confirmed that telia on wheat straw, aecia produced on
B. chinensis, and uredinia produced on Line E were that of $P$. striiformis f. sp. tritici (Table 1; Fig. 2).

\section{DISCUSSION}

Aecial infections on Berberis spp. (B. chinensis, B. koreana, and Emerald Carousel) were observed in June of 2009. This was unusual, in that these Berberis spp. are thought to be resistant to $P$. graminis, the most common rust pathogen of Berberis in North America. Inoculation studies and DNA analysis determined that the aecial infections were caused by $P$. striiformis f. sp. poae. This finding represents the first identification of an alternate host for any type of the stripe rust pathogen. In order to prove that Berberis spp. is an alternative host for P. striiformis f. sp. tritici, teliospores from stripe rust-infected wheat were used to inoculate Berberis spp., and the resultant aeciospores were used to inoculate wheat. These inoculation experiments elucidated the complete life cycle of $P$. striiformis f. sp. tritici (Fig. 3) and unequivocally proved that Berberis spp. are alternate hosts of $P$. 


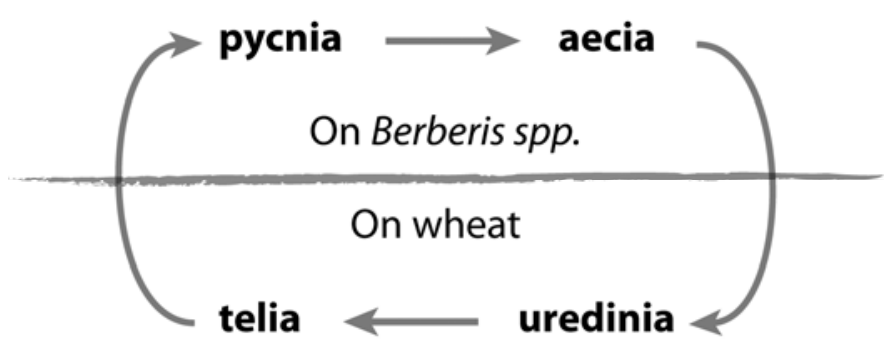

Fig. 3. Life cycle of Puccinia striiformis f. sp. tritici.

striiformis f. sp. tritici. DNA analysis was used to confirm the identity of the rust pathogen at each step in the life cycle. This discovery will likely provide a powerful tool to rapidly advance our knowledge on the genetics of this rust fungus and lead to the development of improved strategies for better control of stripe rust.

P. striiformis f. sp. tritici is known to be one of the most variable cereal rust pathogens with regard to virulence (8). Many new races are regularly identified in wheat producing areas where stripe rust is a major disease. This variability in virulence has been attributed to mutations and somatic hybridization (12) since the sexual stage was presumed to be absent. Our discovery of an alternate host has led us to hypothesize that in areas where wheat and susceptible barberry species coexist, sexual recombination has likely played an active role in contributing to pathogen variability. This hypothesis needs to be tested by isolating new races of $P$. striiformis f. sp. tritici from Berberis spp. The high degree of virulence diversity found in western China (3), the Caucasus and Central Asia (13) where B. vulgaris and B. chinensis grow naturally, and a highly aggressive race originating from eastern Africa where B. holstii is present, serve as indirect evidence to support this hypothesis. Wide use of ornamental Berberis spp. identified to be susceptible in this study, and the likely discovery of other susceptible species and hybrids to $P$. striiformis f. sp. tritici, highlights the concern that ornamental Berberis spp. has the potential for generating novel virulence combinations.

\section{ACKNOWLEDGMENTS}

We thank S. Gale, K. P. Nguyen, J. Johnson, L. Wanchura, and M. Hughes for their technical assistance. We also thank I. Lowe (UC Davis) for harvesting and providing wheat leaves bearing telia of $P$. striiformis $\mathrm{f}$. sp. tritici. Mention of a trademark, vendor, or proprietary product does not constitute a guarantee or warranty of the product by the United States
Department of Agriculture and does not imply its approval to the exclusion of other product or vendor that also may be suitable.

\section{LITERATURE CITED}

1. Anikster, Y., Szabo, L. J., Eilam, T., Manisterski, J., Koike, S. T., and Bushnell, W. R. 2004. Morphology, life cycle biology, and DNA sequence analysis of rust fungi on garlic and chives from California. Phytopathology 94:569-577.

2. Barnes, C. W., and Szabo, L. J. 2007. Detection and identification of four common rust pathogens of cereals and grasses using real-time polymerase chain reaction. Phytopathology 97:717-727.

3. Chen, W. Q., Wu, L. R., Liu, T. G., Xu, S. C., Jin, S. L., Peng, Y. L., and Wang, B. T. 2009. Race dynamics, diversity, and virulence evolution in Puccinia striiformis f. sp. tritici, the causal agent of wheat stripe rust in China from 2003 to 2007. Plant Dis. 93:1093-1101.

4. Eriksson, J., and Henning, E. 1894. Die Hauptresultate einer neuen Untersuchung über die Getreiderostpilze. Z. Pflanzenkr. 4:197-203.

5. Hart, H., and Becker, H. 1939. Beitrage zur Frage des Zwischenwirtes für Puccinia glumarum. Z. Pflanzenkr. (Pflanzenpathol.) Pflanzenschutz 49:559-566.

6. Hassebrauk, K. 1970. Der Gelbrost Puccinia striiformis West. 2 Befallsbild. Morphologie and giologie der Sporen. Infektion und weitere Entwickhlung. Wirkungen auf die Wirtspflanze. Mitt. Bio. Bundesanst. LandForstwirsch. Berlin-Dahlem 139:1-111.

7. Jin, Y., and Steffenson, B. J. 1999. Puccinia coronata var. hordei var. nov: Morphology and pathogenicity. Mycologia 91:877-884.

8. Kolmer, J., Chen, X., and Jin, Y. 2009. Diseases which challenge global wheat production-The wheat rusts. Pages 89-124 in: Wheat, Science and Trade. B. E. Carver, ed. Wiley-Blackwell, Ames, IA.

9. Levine, M. N., and Cotter, R. U. 1932. Susceptibility and resistance of Berberis and related genera to Puccinia graminis. U.S. Dep. Agric. Technol. Bull. no. 300

10. Mains, E. B. 1933. Studies concerning heteroecious rusts. Mycologia 25:407-417.

11. Straib, W. 1937. Untersuchungen über das Vorkommen physiologischer Rassen des Gelbrostes (Puccinia glumarum) in den Jahren 1935-1936 und über die Agressivitt einiger neur Formen auf Getreide und Grasern. Arb. Biol. Reichsanst. LandForstwirtsch. Berlin-Dahlem 22:91-119.

12. Stubbs, R. W. 1985. Stripe rust. Pages 61-101 in: The Cereal Rusts, Volume II. A. P. Roelfs and W. R. Bushnell, eds. Academic Press, Orlando, FL.

13. Stubbs, R. W. 1988. Pathogenicity analysis of yellow (stripe) rust of wheat and its significance in a global context. Pages 23-38 in: Breeding Strategies for Resistance to the Rusts of Wheat. N. W. Simmonds and S. Rajaram, eds. CIMMYT, Mexico, D.F.

14. Szabo, L. J. 2006. Deciphering species complexes: Puccinia andropogonis and Puccinia coronata, examples of differing modes of speciation. Mycoscience 47:130-136.

15. Tranzschel, W. 1934. Promezutocnye chozjaeva rzavciny chlebov i ich der UdSSR (The alternate hosts of cereal rust fungi and their distribution in the UdSSR). Bull. Plant Prot. Ser. 2:4-10. (In Russian with German summary.) 